University of Nebraska - Lincoln

DigitalCommons@University of Nebraska - Lincoln

Publications, Agencies and Staff of the U.S.

Department of Commerce

U.S. Department of Commerce

10-2001

\title{
Movements and Population Structure of Humpback Whales in the North Pacific
}

John Calambokidis

Gretchehn Steiger

Janice Straley

Alaska

Louis Herman

Kewalo Basin Marine Mammal Laboratory, University of Hawaii, 1129 Ala Moana Boulevard, Honolulu, Hawaii

Salvatore Cerchio

Moss Landing Marine Laboratories, P. 0. Box 450, Moss Landing, California

See next page for additional authors

Follow this and additional works at: https://digitalcommons.unl.edu/usdeptcommercepub

Part of the Environmental Sciences Commons

Calambokidis, John; Steiger, Gretchehn; Straley, Janice; Herman, Louis; Cerchio, Salvatore; Salden, Dan; Urban R., Jorge; Jacobsen, Jeff; von Ziegesar, Olga; Balcomb, Kenneth; Gabriele, Christine; Dahlheim, Marilyn; Uchida, Senzo; Ellis, Graeme; Miyamura, Yukifumi; Ladron de Guevara P., Paloma; Yamaguchi, Manami; Sato, Fumihiko; Mizroch, Sally; Schlender, Lisa; Barlow, Jay; and Quinn, Terrance II, "Movements and Population Structure of Humpback Whales in the North Pacific" (2001). Publications, Agencies and Staff of the U.S. Department of Commerce. 172.

https://digitalcommons.unl.edu/usdeptcommercepub/172

This Article is brought to you for free and open access by the U.S. Department of Commerce at DigitalCommons@University of Nebraska - Lincoln. It has been accepted for inclusion in Publications, Agencies and Staff of the U.S. Department of Commerce by an authorized administrator of DigitalCommons@University of Nebraska - Lincoln. 


\section{Authors}

John Calambokidis, Gretchehn Steiger, Janice Straley, Louis Herman, Salvatore Cerchio, Dan Salden, Jorge Urban R., Jeff Jacobsen, Olga von Ziegesar, Kenneth Balcomb, Christine Gabriele, Marilyn Dahlheim, Senzo Uchida, Graeme Ellis, Yukifumi Miyamura, Paloma Ladron de Guevara P., Manami Yamaguchi, Fumihiko Sato, Sally Mizroch, Lisa Schlender, Jay Barlow, and Terrance Quinn II 


\title{
MOVEMENTS AND POPULATION STRUCTURE OF HUMPBACK WHALES IN THE NORTH PACIFIC
}

\author{
John Calambokidis \\ Gretchen H. Steiger \\ Cascadia Research Collective,
}

2181/2 West Fourth Avenue, Olympia, Washington 98501, U.S.A.

E-mail: calambokidis@cascadiaresearch.org

Janice M. Straley

P. O. Box 273, Sitka, Alaska 99835, U.S.A.

Louis M. Herman

Kewalo Basin Marine Mammal Laboratory,

University of Hawaii, 1129 Ala Moana Boulevard, Honolulu, Hawaii 96814, U.S.A.

Salvatore Cerchio ${ }^{1}$

Moss Landing Marine Laboratories,

P. O. Box 450, Moss Landing, California 95039 U.S.A.

DAN R. SALDEN

Hawaii Whale Research Foundation, Southern Illinois University at Edwardsville,

Edwardsville, Illinois 62026, U.S.A.

JoRge URBÁN R.

Departamento de Biología Marina,

Universidad Autónoma de Baja California Sur, Ap. Post 19-B, B.C.S. 23081, Mexico

JEFF K. JACOBSEN

P. O. Box 4492, Arcata, California 95521, U.S.A.

Olga von Ziegesar

North Gulf Oceanic Society,

P. O. Box 15244, Homer, Alaska 99603, U.S.A.

KenNeth C. Balcomb

Center for Whale Research, 1359 Smuggler's Cove Road, Friday Harbor, Washington 98250, U.S.A.

Christine M. Gabriele

Glacier Bay National Park,

P. O. Box 140, Gustavus, Alaska 99826, U.S.A. 


\title{
Marilyn E. DaHLHEIM
}

National Marine Mammal Laboratory, NOAA, 7600 Sand Point Way NE, Seattle, Washington 98115, U.S.A.

SENZO UCHIDA

Okinawa Expo Aquarium, Motobu-cho, Okinawa-ken 905-03, Japan

Graeme Elisis

Department of Fisheries and Oceans, Pacific Biological Station,

Nanaimo, British Columbia V9R 5K6, Canada

\section{YUKIFUMI MIYAMURA}

World Wide Fund for Nature-Japan, Tokyo, Japan

Paloma Ladrón de Guevara P.

Laboratorio de Mamiferos Marinos, Universidad Nacional Autónoma de México, Ap. Post 70-572, México Ciry, D.F 04510, Mexico

\section{Manami Yamaguchi Fuminiko Sato}

Ogasawara Marine Center,

Byobudani, Chichijima, Ogasawara-mura, Tokyo 100-21, Japan

\section{Saliy A. Mizroch}

National Marine Mammal Laboratory, NOAA,

7600 Sand Point Way NE, Seattle, Washington 98115, U.S.A.

\section{Lisa SCHLENDER}

Kristin Rasmussen

Cascadia Research Collective,

2181/2 West Fourth Avenue, Olympia, Washington 98501, U.S.A.

$$
\text { JAY BARLOW }
$$

Southwest Fisheries Science Center,

National Marine Fisheries Service,

P. O. Box 271, La Jolla, California 92038, U.S.A.

\section{Terrance J. Quinn II}

University of Alaska Fairbanks,

11120 Glacier Highway, Juneau, Alaska 99801, U.S.A.

\begin{abstract}
Despite the extensive use of photographic identification methods to investigate humpback whales in the North Pacific, few quantitative analyses have been conducted. We report on a comprehensive analysis of interchange in the North Pacific among three wintering regions (Mexico, Hawaii, and Japan)
\end{abstract}


each with two to three subareas, and feeding areas that extended from southern California to the Aleutian Islands. Of the 6,413 identification photographs of humpback whales obtained by 16 independent research groups between 1990 and 1993 and examined for this study, 3,650 photographs were determined to be of suitable quality. A total of 1,241 matches was found by two independent matching teams, identifying 2,712 unique whales in the sample (seen one to five times). Site fidelity was greatest at feeding areas where there was a high rate of resightings in the same area in different years and a low rate of interchange among different areas. Migrations between winter regions and feeding areas did not follow a simple pattern, although highest match rates were found for whales that moved between Hawaii and southeastern Alaska, and between mainland and Baja Mexico and California. Interchange among subareas of the three primary wintering regions was extensive for Hawaii, variable (depending on subareas) for Mexico, and low for Japan and reflected the relative distances among subareas. Interchange among these primary wintering regions was rare. This study provides the first quantitative assessment of the migratory structure of humpback whales in the entire North Pacific basin.

Key words: humpback whale, Megaptera novaeangliae, population structure, movements, North Pacific, photo-identification, interchange, migration.

The geographic structure of humpback whale populations in the North Pacific has been derived from: (1) accounts from commercial catches (Kellogg 1928, Tomilin 1957, Berzin and Rovnin 1966) and movements based on Discovery tag recoveries (Nishiwaki 1966, Omura and Ohsumi 1964, Ohsumi and Masaki 1975, Ivashin and Rovnin 1967), (2) movements determined from photographically identified humpback whales (Darling and Jurasz 1983; Darling and McSweeney 1985; Baker et al. 1986; Darling and Mori 1993; Calambokidis et al. 1996, 2000; Steiger et al. 1991; Darling and Cerchio 1993; Darling et al. 1996; Waite et al. 1999; Urbán et al. 2000), (3) geographic differences in genetic patterns of humpback whales based either on mtDNA (Baker et al. 1990, 1994; Medrano-González et al. 1995) or nuclear DNA (Baker et al. 1993, 1998; Palumbi and Baker 1994), (4) geographic differences in the songs (Helweg et al. 1990, Payne and Guinee 1983), and (5) differences in the proportion of whales with different fluke coloration patterns (Baker et al. 1985, 1986; Allen et al. 1994; Pike 1953; Rosenbaum et al. 1995).

Despite these studies, no clear consensus exists on the structure of humpback whale populations in the North Pacific. The International Whaling Commission considers humpback whales in the North Pacific as one "stock" for management purposes (Donovan 1991). Evidence of at least some intermixing among wintering regions has led some researchers to suggest these constitute one or at most two "stocks" (Darling and McSweeney 1985, Darling and Cerchio 1993, Darling et al. 1996). Baker et al. (1994) concluded that humpback whales in the eastern North Pacific could be divided into at least two groups or "stocks" based on genetic evidence: a central stock that feeds in

\footnotetext{
${ }^{1}$ Current address: University of Michigan, 1109 Geddes Avenue, Ann Arbor, Michigan 48109, U.S.A.
} 
Alaskan waters and migrates predominantly to Hawaii, and an "American" stock that feeds along the coast of California and winters off Mexico. Barlow (1994) and Barlow et al. (1997) concluded that, based on the need to define conservative population units, humpback whales in the North Pacific should be divided into four migratory populations. They described these separate migratory populations as the coastal California/Oregon/Washington-Mexico stock, the Mexico offshore (Revillagigedos) stock (feeding destination unknown), the central North Pacific stock (Hawaii-Alaska), and the western North Pacific stock (Japan-feeding destination unknown).

Photographic identification of individual humpback whales has proved to be valuable in describing movements of animals among wintering or feeding areas, as well as in describing the dynamics of movements within areas. Unfortunately, these studies often have been limited to a few sites and have not provided a quantitative assessment of the rates of interchange.

Here we describe the population structure and movements of humpback whales in the North Pacific based on a large collaborative effort among 16 research groups that collected identification photographs throughout the North Pacific from 1990 to 1993. The years and collections used were designed to provide a broadly distributed sample across the entire North Pacific Ocean. These data are integral to the calculation and interpretation of a geographically stratified mark-recapture abundance estimate of humpback whales in the North Pacific basin which will be published separately.

\section{Methods}

\section{Selection of Photographs}

This project encompassed all locations in the North Pacific where photoidentification research has been conducted (Fig. 1, Table 1). These included three wintering regions (Mexico, Hawaii, and Japan), each with two or three subareas, and feeding areas that extended from southern California to the Aleutian Islands. The years 1991-1993 were selected because samples throughout the entire North Pacific were the largest and the most complete during this period. The sample from Mexico also included 174 suitable identification photographs from 1990 taken off mainland Mexico and Baja (Table 1) to obtain a more representative sample from this region. In all of the studies the natural marks on the ventral side of the flukes were photographed. Field methods of many of these studies have been described (e.g., Calambokidis et al. 1990, 1996; Cerchio 1998; Cerchio et al. 1998; Waite et al. 1999; Darling and Mori 1993; Uchida et al. 1993; von Ziegesar et al. 1994).

Photographs of each individual whale identified were provided as blackand-white prints or negatives, or color slides. Custom black-and-white prints $(6.4 \times 8.9 \mathrm{~cm})$ were made for all the negatives. Within-year duplicates in each collection were removed. We received and screened a sample of 6,414 identification photographs (Table 1).

Each photograph was graded from highest quality (1) to lowest quality (5) 


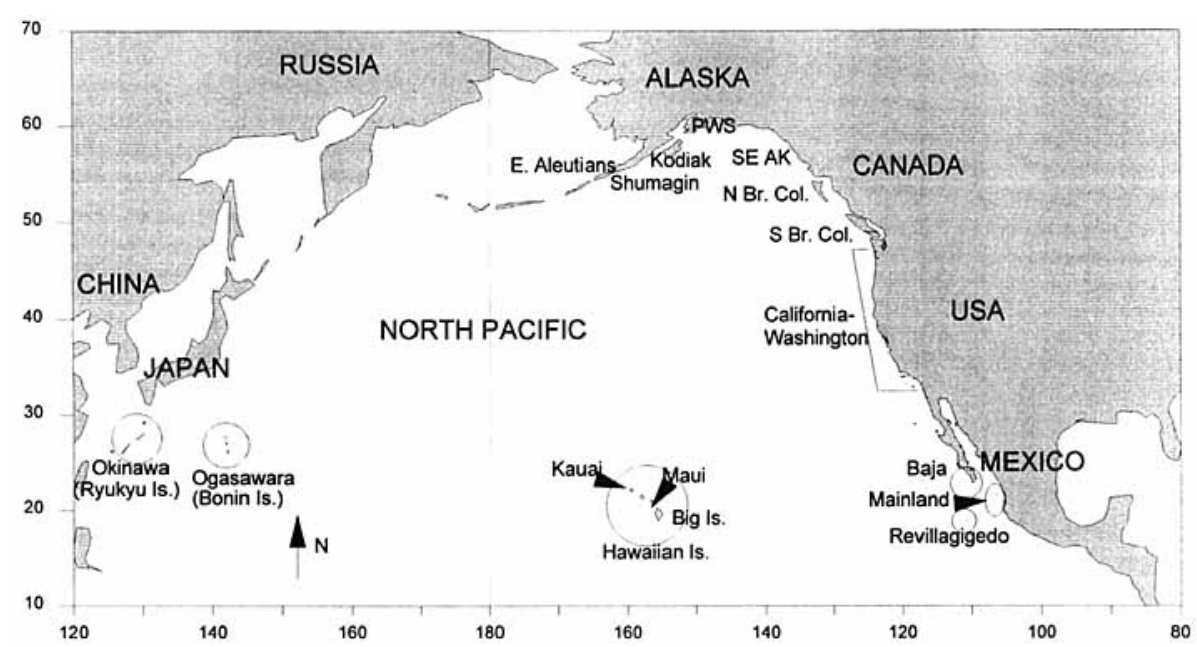

Figure 1. Locations where photographic identification data were collected that were used in this study.

using a uniform set of criteria to select the sample of photographs used for the comparison. Quality was judged on each of six variables: the proportion of the fluke that was visible, fluke angle (i.e., how perpendicular it was to the water), the lateral angle of the photographer, the sharpness and grain, fluke size on print, and the photographic quality (lighting, exposure, and contrast). Because some of these measures were clearly subjective, photograph archetypes for the different codes were used during the scoring process. Photographs that were graded a 4 or 5 in any category or that received a 3 in three or more categories were rejected. Selected and rejected photographs were then checked visually and recoded in certain cases where photographs appeared to have been scored incorrectly. Before the comparison began, all photographs from each collection were divided into five subcategories based on the proportion of light and dark coloration of the flukes. Photographs of calf flukes were excluded because markings have the potential to change in the first year (Carlson et al. 1990). Of the 6,414 identification photographs obtained, 3,650 were selected for comparison (Table 1).

\section{Comparison of Photographs}

Two matching teams made independent comparisons of the entire collection. Photographs were compared based on the coloration, trailing edge, scars and other markings on the flukes. At least one member of each team compared each photograph to all other photographs. Another redundancy built into the process was that photographs, once compared, were returned to the sample. Therefore, there were two opportunities for each team to match two photographs (except for the 1990 Mexico photographs which were added later in the process). Matches were recorded independently and were not discussed 


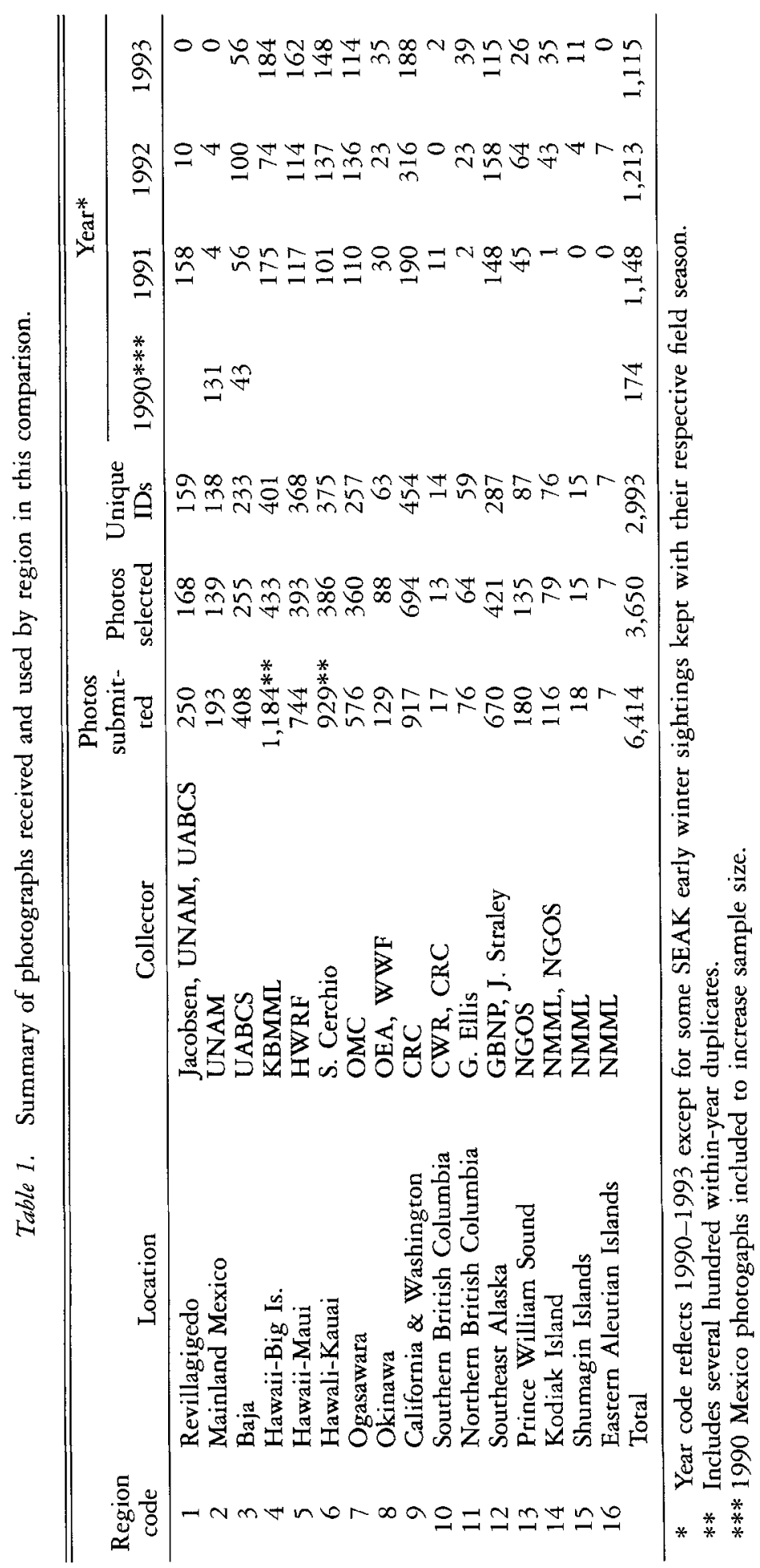


among the team members. When the comparison was complete, all matches found by only one team were verified by the second team. Where a match suggested unusual or undocumented movements between locations, the photographs were checked a second time. The success rate of finding matches was calculated based on comparison of the matches found between the two independent teams, as well as their success in finding matches known by the contributing teams (but to which the matchers were blind).

\section{Match Index}

A match index was calculated to provide a relative measure of the amount of movement between regions. We used the match index for various combinations of years. This index (previously termed "Interchange Index") is basically the inverse of the Petersen capture-recapture index and has been previously used to examine the rate of interchange of humpback whales among areas (e.g., Baker et al. 1986; Urbán et al. 1999, 2000). Let

$$
a_{i}=\text { number of marked releases at time } 1 \text { in region } i, i=1, \ldots, R \text {, }
$$$$
n_{j}=\text { number examined for marks at time } 2 \text { in region } j \text {, }
$$

$m_{i \rightarrow j}=$ marked recaptures in region $j$ originally marked in region $i$,

$$
p_{j}=\text { probability of capture in region } j \text {, }
$$

$\theta_{i \rightarrow j}=$ probability that a marked release from region $i$ moves to region $j$,

$$
N_{j}=\text { population abundance in region } j \text {. }
$$

The match index can be written

$$
I_{i \rightarrow j}=\left[m_{i \rightarrow j} /\left(a_{i} n_{j}\right)\right] \times 1,000 .
$$

The expected value of this index can be found in a straightforward manner. First, the expected value of the number of marked recaptures is $E\left(m_{i \rightarrow j}\right)=$ $a_{i} \theta_{i \rightarrow j} p_{j}$, because the expected number of marked recaptures is the number originally marked in region $i$ that move to region $j$ and that are captured there. If a simple random sample is taken at time 2 , then the probability of capture is $p_{j}=n_{j} / N_{j}$. By combining these relationships, the expected value of the index is

$$
E\left(I_{i \rightarrow j}\right)=\theta_{i \rightarrow j} / N_{j} \times 1,000
$$

which shows that the expected value of the index is directly proportional to the movement probability and inversely proportional to abundance. A high value of this index occurs as a result of a small population being present or a small movement probability, while a low value occurs due to either a large population or an unlikely interchange of animals. Note that if $i=j$, then the 
movement probability is the probability of remaining in the same region, and the index is a relative measure of return.

Means of multiple match indices are accompanied with the standard error for the estimates (based on the variation in the observed values without a calculation of their inherent variance).

\section{REsulTs}

\section{Evaluation of Matcbing Success}

Of our sample of 3,650 photographs, there were 1,220 pairs of matches found by one or both teams. Each team found $93 \%-94 \%(1,141$ and 1,149$)$ of the matches. A Peterson capture-recapture calculation (using total matches found by each team as $n_{1}$ and $n_{2}$ and the number of these found in common by both teams as $m_{12}$ ) yielded an estimate that $99.6 \%$ of the matches would have been found by at least one team. This estimate, however, is biased upwards because matches found by each team were not truly independent events; some whales were easier or harder to match than others for both teams. We also measured our success in finding matches that were known by the contributors but to which our teams were blind. These were generally interyear matches within their collections that they had a high degree of success finding because of their familiarity with their smaller collections. Of the 620 matches provided to us by the contributors (involving whales in our comparison), 599 (97\%) were found by one or both teams. This is a more unbiased assessment of our matching success rate. The 21 matches missed by our teams were included in our analyses (total of 1,241 matches) but no other correction was made for the low rate of missed matches.

\section{Total Matches and Unique Whales}

Based on matches found, our sample of 3,650 photographs represented 2,712 unique whales, 2,003 seen only once and 709 whales seen two to five times (Table 2). Of the 1,241 pairs of matches, those involving whales seen within the same region were more common than those between regions and accounted for 808 (65\%) of the matches. Because catalogs from each area had been already internally compared and duplicate photographs eliminated, most of these matches were of whales seen in different years in the same area. A disproportionate number of resightings was made in feeding areas (550) compared to wintering regions (258). The rate of resightings within a region or area (as measured by the match index, Table 3) varied, with highest resighting rates at the two subareas off Japan and at most feeding areas (Prince William Sound, southeastern Alaska, British Columbia, and California-Washington). Whales identified off Kodiak and in the western Gulf of Alaska were the only feeding-area samples with low resighting rates. Rates of among-year resightings within regions reflect the size of the overall population being sampled and the degree of site fidelity. 


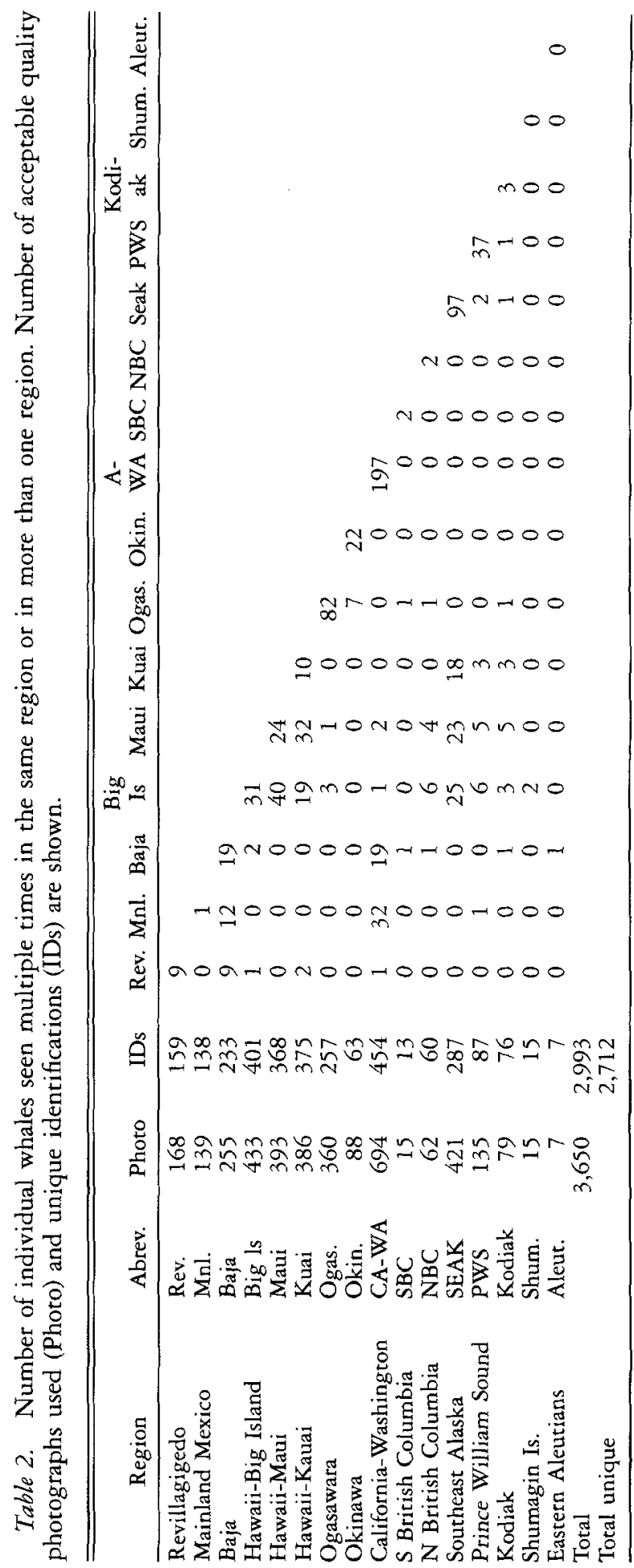


Table 3. Match index among years for each location sampled. British Columbia and W. Gulf of Alaska pooled due to sample size.

\begin{tabular}{llccc}
\hline \hline Code & \multicolumn{1}{c}{ Location } & $n$ (yr) & Index & SE \\
\hline 1 & Revillagigedo & 1 & 1.32 & \\
2 & Mainland Mexico & 2 & 0.95 & 0.95 \\
3 & Baja & 6 & 1.00 & 0.24 \\
4 & Hawaii-Big Island & 3 & 0.27 & 0.02 \\
5 & Hawaii-Maui & 3 & 0.39 & 0.09 \\
6 & Hawaii-Kauai & 3 & 0.25 & 0.05 \\
7 & Ogasawara & 3 & 2.89 & 0.10 \\
8 & Okinawa & 3 & 11.64 & 3.09 \\
9 & California \& Washington & 3 & 1.82 & 0.04 \\
$10 \& 11$ & British Columbia & 3 & 2.12 & 0.66 \\
12 & Southeast Alaska & 3 & 2.80 & 0.20 \\
13 & Prince William Sound & 3 & 10.72 & 1.05 \\
14 & Kodiak & 3 & 0.66 & 0.66 \\
$15 \& 16$ & Shum./Aleut. & 1 & 0.00 & \\
\hline
\end{tabular}

\section{Interchange Among and Witbin Wintering Regions}

Within-region movements-Movements and interchange among the three $\mathrm{Ha}-$ waii subareas was extensive (Table 2,4 ). The same whales were seen in multiple subareas both in the same year and in different years. The mean match index for whales at the same subarea in different years $(0.306)$ was only slightly higher than that between subareas in different years (0.264). This indicates that whales were equally likely to return to a different subarea as they were

Table 4. Match indices for different combinations of years and regions for three subareas in Hawaii 1991-1993. Same area in different year values were averaged for three combinations of years (1991-1992, 1991-1993, 1992-1993) at each subarea. Different areas in same year values were averaged for pairs of subareas for three sample years $(1991,1992,1993)$. Different areas in different year values were pooled for each pair of subareas in combinations of different years.

\begin{tabular}{lccc}
\hline \hline \multicolumn{1}{c}{ Samples } & $n$ & Mean & SE \\
\hline Same area in different years & 9 & 0.306 & 0.038 \\
Big Island & 3 & 0.271 & 0.024 \\
Maui area & 3 & 0.395 & 0.089 \\
Kauai & 3 & 0.253 & 0.054 \\
Different areas in same year & 9 & 0.138 & 0.042 \\
Big Island-Maui & 3 & 0.254 & 0.057 \\
Maui-Kauai & 3 & 0.108 & 0.078 \\
Big Island-Kauai & 3 & 0.053 & 0.036 \\
Different areas and years & 18 & 0.264 & 0.043 \\
Big Island-Maui & 6 & 0.306 & 0.102 \\
Maui-Kauai & 6 & 0.276 & 0.062 \\
Big Island-Kauai & 6 & 0.211 & 0.062 \\
All & 36 & 0.243 & $\mathbf{0 . 0 2 7}$ \\
\hline
\end{tabular}


Table 5. Match indices for different combinations of years and regions for three subareas in Mexico 1990-1993 (see Table 4 for explanation). Small samples only used for within-area calculations.

\begin{tabular}{lccc}
\hline \multicolumn{1}{c}{ Samples } & $n$ & Mean & SE \\
\hline Same area in different years & 9 & $\mathbf{0 . 9 5 0}$ & 0.225 \\
Mainland & 2 & 0.954 & 0.954 \\
Revillagigedos & 1 & 1.324 & \\
Baja & 6 & 0.997 & 0.240 \\
Different areas in same year & 2 & $\mathbf{0 . 2 9 8}$ & 0.057 \\
Mnld-Baja & 1 & 0.355 & \\
Rev-Baja & 1 & 0.241 & \\
Different areas and years & 7 & $\mathbf{0 . 2 5 8}$ & 0.063 \\
Mnld-Baja & 3 & 0.380 & 0.088 \\
Rev-Baja & 3 & 0.221 & 0.034 \\
Rev-Mnld & 1 & 0.000 & \\
All & $\mathbf{1 8}$ & $\mathbf{0 . 6 0 8}$ & 0.139 \\
\hline
\end{tabular}

to return to the same subarea in successive years. Only the among-subarea match index in the same year was lower $(0.138)$, indicating whales were not as likely to travel to multiple subareas in the same year as they were to return to the same or a different subarea in a different year.

Interchange among the Mexico subareas was less extensive and showed some clear preferred directions of interchange, although sampling among subareas and years was incomplete (Table 5). The highest index values were obtained for whales returning to the same subarea in different years $(0.95)$. No interchange was seen between the mainland Mexico and Revillagigedo subareas, although large samples (more than 100 individuals) were available only for 1991 from the Revillagigedos and 1993 from mainland Mexico. Interchange among subareas was most common between mainland and Baja, both for the same year and among years (match indices of 0.355 and 0.380 , respectively). Interchange between the Revillagigedos and Baja was only slightly lower $(0.221$ and 0.241$)$. This suggests that Baja may be primarily a migratory corridor where whales from both the Revillagigedos and mainland overlap. Thus, the Baja subarea was more representative of the Mexico wintering region as a whole than either of the other two subareas. The sample from Baja was larger and included four years (1990-1993) compared to only the single-year large samples from the other two subareas.

Off Japan the match index for different years in the same subarea was much higher than that within Mexico and Hawaii, indicating a high rate of return of a small population (Table 6). This was especially true off Okinawa where the index was four times higher than off Ogasawara (11.6vs. 2.9). Although movement between these two subareas was documented in both the same year and in different years, the match index was more than an order of magnitude lower than that for return to the same subarea in different years.

Interchange between regions-Interchange between wintering regions was seen, but occurred infrequently. The match indices between any two wintering re- 
Table 6. Match indices for different combinations of years and locations for 2 subareas in Japan 1991-1993 (see Table 4 for explanation).

\begin{tabular}{lrrc}
\hline \hline \multicolumn{1}{c}{ Samples } & $n$ & Mean & SE \\
\hline Same area in different years & 6 & 7.265 & 2.395 \\
$\quad$ Okinawa & 3 & 11.636 & 3.093 \\
$\quad$ Ogasawara & 3 & 2.893 & 0.096 \\
$\begin{array}{l}\text { Different areas in same year } \\
\quad \text { Okin.-Ogas. }\end{array}$ & 3 & 0.167 & 0.167 \\
Different areas and years & 6 & 0.244 & 0.084 \\
$\quad$ Okin.-Ogas. & 15 & 3.037 & 1.293 \\
All & & & \\
\hline
\end{tabular}

gions were one to two orders of magnitude lower than the among-year rate for the same region (Table 7). Six transits of five individual whales were documented between Mexico and Hawaii: three of these whales traveled between the Revillagigedos and Hawaii and two between Baja and Hawaii. Four transits of three whales were found between Hawaii and Japan (Fig. 2). One whale made multiple transits between Hawaii and Japan (Maui in 1991, Ogasawara in 1992, and off the Big Island of Hawaii in 1993). None of these whales were seen in more than one wintering region in the same year. No exchange was found between Mexico and Japan.

\section{Interchange Among Feeding Areas}

There was little interchange among different feeding areas. At five of the eight feeding areas, no between-area matches were found. Only four whales were found to have traveled to different feeding areas. Of the 287 whales photographed in southeastern Alaska, two were seen in Prince William Sound (87) and one was seen off Kodiak (69). Additionally, a single whale was seen

Table 7. Match indices for different combinations of years and pooled wintering regions (see Table 4 for explanation).

\begin{tabular}{llll}
\hline \multicolumn{1}{c}{ Samples } & $n$ & Mean & SE \\
\hline Same region in different years & 6 & 0.518 & 0.103 \\
$\quad$ Mexico & 3 & 0.257 & 0.032 \\
$\quad$ Hawaii & 3 & 2.365 & 0.090 \\
Japan & 3 & 0.000 & 0.000 \\
Different regions in same year & 3 & 0.000 & 0.000 \\
$\quad$ Mexico-Hawaii & 3 & 0.000 & 0.000 \\
Hawaii-Japan & & & \\
Mexico-Japan & 9 & 0.015 & 0.007 \\
Different regions and years & 6 & 0.010 & 0.005 \\
$\quad$ Mexico-Hawaii & 9 & 0.000 & 0.000 \\
Hawaii-Japan & & & \\
Mexico-Japan & &
\end{tabular}




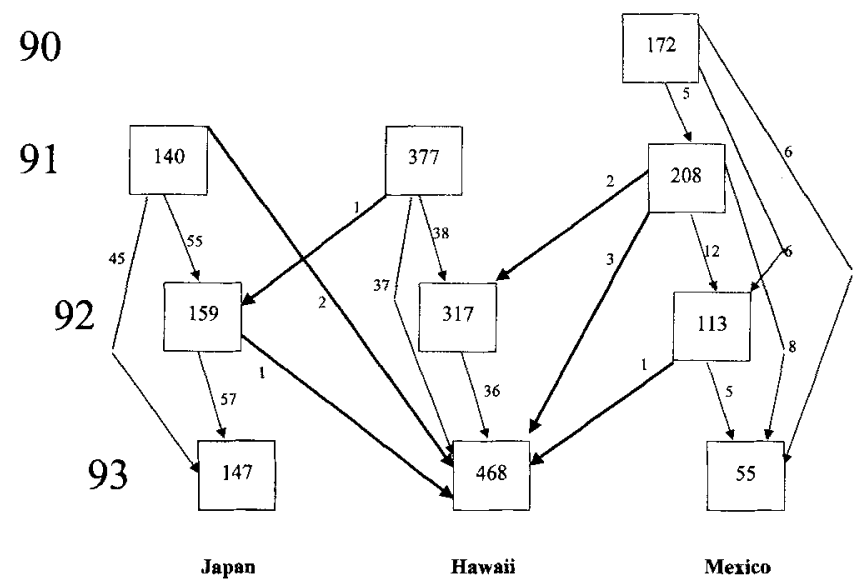

Figure 2. Interyear and interregion matches between the wintering regions off Japan, Hawaii, and Mexico. Numbers in boxes show number of individuals; numbers next to lines show number of whales that matched between years or regions.

both off Kodiak and in Prince William Sound. In all but one case these matches were of whales seen in different years. The exception was one animal that moved between Prince William Sound and southeastern Alaska in the same year (July and November 1992).

\section{Migratory Movements}

Whales from each of the three wintering regions were found at multiple feeding areas in the North Pacific (Fig. 3-5, Table 8). Additionally there were

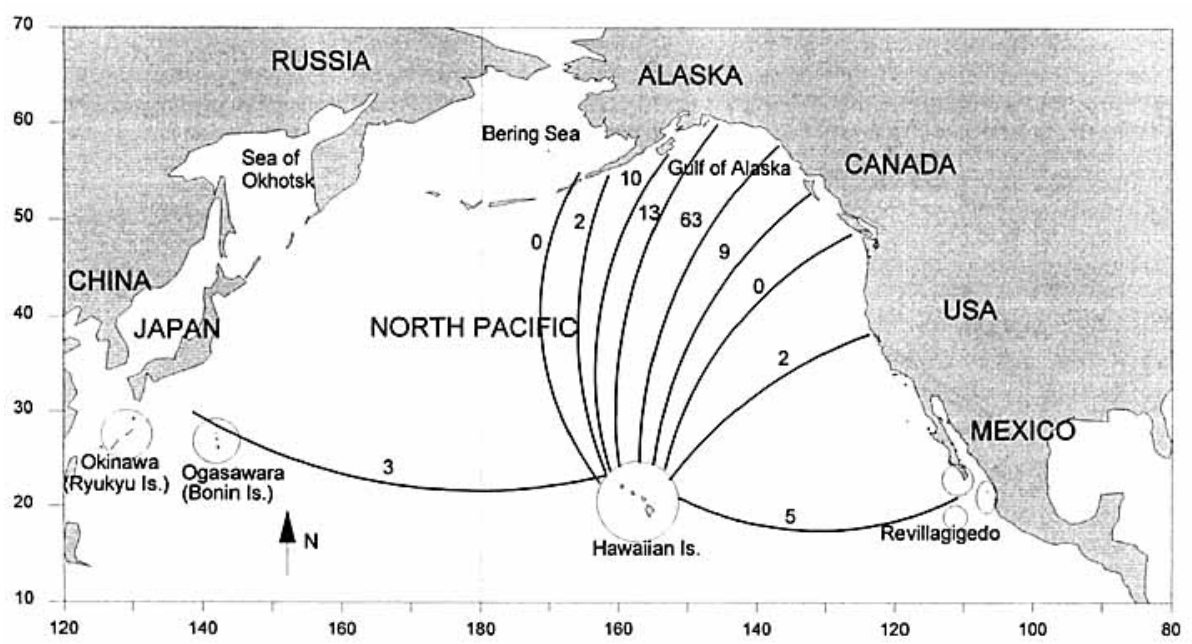

Figure 3. Number of whales seen in Hawaii $(n=1,056)$ that were also identified at other locations. 


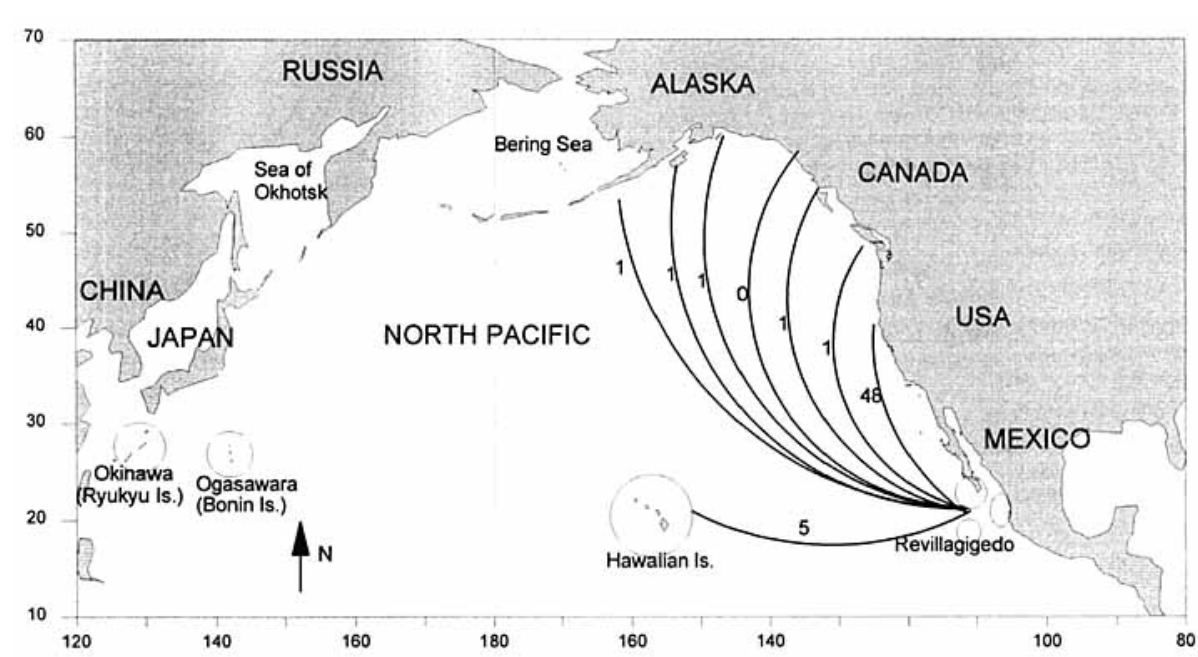

Figure 4. Number of whales seen off Mexico $(n=509)$ that were also identified at other locations.

differences among subareas in the migratory destinations of whales wintering in Mexico and Japan.

Overall, whales photographed off Mexico were most likely to be resighted off California (match index $=0.208$ ), although they were also seen off northern and southern British Columbia, Prince William Sound, Kodiak and the Aleutian Islands (Fig. 4). Differences among subareas of Mexico were substantial, however (Table 8). Whales identified off mainland Mexico had a very high match index with California, those identified off Baja had an intermediate index with four different feeding areas, and those identified off the Revilla-

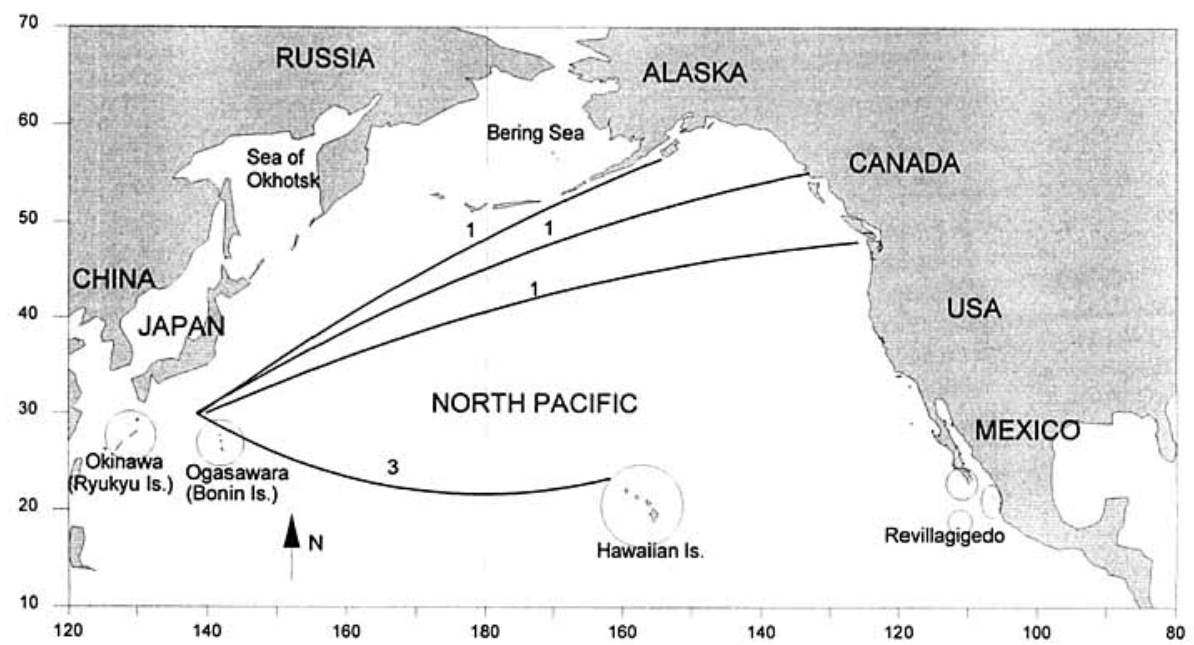

Figure 5. Number of whales seen off Japan $(n=313)$ that were also identified at other locations. 


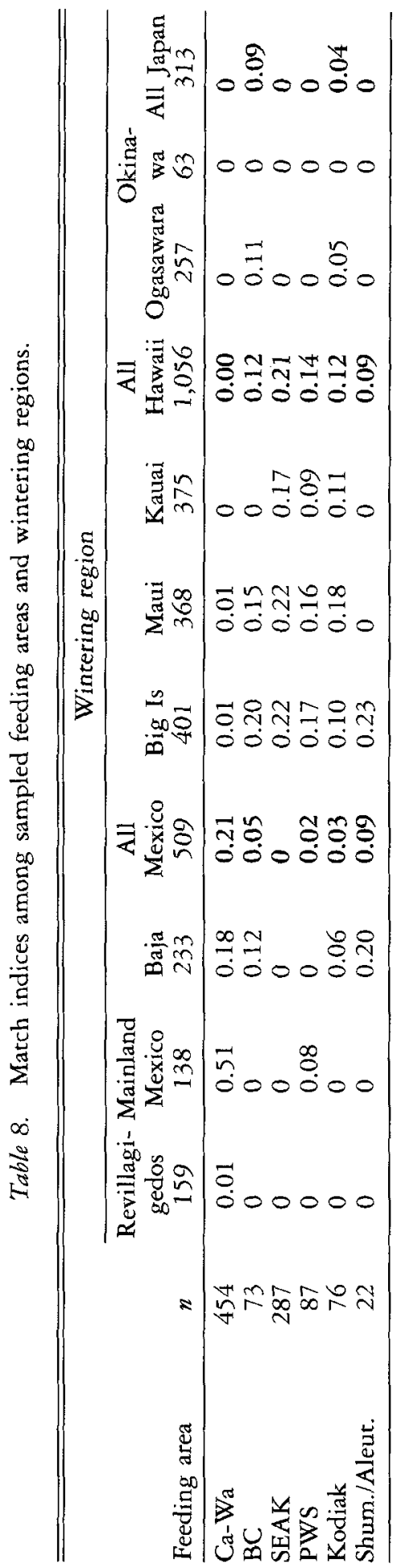


gigedos had a low match index with all sampled feeding grounds. Of the 159 individuals photographed off the Revillagigedo Archipelago, only one was seen at any feeding area (off California).

Whales identified in all three subareas of Hawaii were seen in multiple feeding areas with the highest overall match index to southeastern Alaska (0.208, Fig. 3, Table 8). Whales identified off Hawaii were also observed off California, northern British Columbia, Prince William Sound, Kodiak Islands, and the Aleutian Islands (Fig. 3). There were no large differences in the match indices by subarea of Hawaii to the different Alaskan feeding areas. Of the 11 whales that were found to move between Hawaii and the easternmost feeding areas from California to British Columbia, none were from Kauai. This is significantly different than would be expected $\left(\chi^{2}=6.4\right.$, df $\left.=2, P<0.05\right)$ if whales from each Hawaii subarea had an equal tendency to migrate to these feeding areas and may indicate that whales seen in the westernmost subarea of the Hawaiian Island chain are less likely to migrate to the easternmost feeding areas.

Only three whales were documented moving between the Japan wintering regions and feeding areas; these consisted of single matches to southern British Columbia, northern British Columbia, and Kodiak Island (Fig. 5, Table 8). All three of these whales were identified off Ogasawara; we found no matches for whales that had been seen off Okinawa.

Whales identified in a specific feeding area sometimes showed a clear preference for a wintering region (Table 8). Whales identified in southeastern Alaska showed a high match index with Hawaii and were not identified in any other wintering region (match index of 0 ). Whales identified off California, Oregon, and Washington were almost exclusively identified in Mexico, with only a few matches with Hawaii. For most other feeding areas, however, migrations were documented to multiple wintering regions. Whales identified off British Columbia, for example, showed a similar match index with Mexico, Hawaii, and Japan.

\section{Discussion}

Movements of humpback whales between some regions have been examined by previous studies using a variety of methods. This study describes some movements that were unknown previously and also confirms many documented findings. Our primary contribution, however, is the use of a broad geographic scope and comparison of quantitative exchange rates among all wintering areas and all studied feeding areas for humpback whales in the North Pacific. This has shown that while the structure of humpback whale populations in the North Pacific is complex there are some clear, interpretable patterns.

\section{Site Fidelity and Interchange Among Wintering Regions}

While interchange of animals between wintering regions was documented, it occurred at a much lower rate compared to animals returning to the same 
wintering region. Movement between wintering regions has been reported previously between Hawaii and Japan (Darling and Cerchio 1993) and Mexico and Hawaii (Darling and Jurasz 1983, Darling and McSweeney 1985, Baker et al. 1986, Perry et al. 1990). While we also found these movements, we demonstrate that the rate of exchange among wintering regions is low, indicating fidelity to these regions.

The wide variations in interchange among subareas for the three primary wintering regions were consistent with the distances among them. Interchange was most extensive among Hawaii subareas where the distances were smallest (less than $500 \mathrm{~km}$ between all subareas), intermediate among Mexico subareas (500-800 km apart), and most limited among the Japan subareas $(1,500 \mathrm{~km}$ apart). The high degree of interchange among subareas of the Hawaiian Islands found in this study and reported previously between some subareas (Baker and Herman 1981, Darling and Morowitz 1986, Darling and McSweeney 1985, Cerchio et al. 1998) supports the conclusion that the waters surrounding the Hawaiian Islands constitute one wintering region. For Mexico, movements among subareas were more stratified. Samples from this study were consistent with the larger sample analyzed by Urbán et al. (1999, 2000) that showed only a low rate of interchange between whales wintering along the mainland and those around the offshore Revillagigedo Islands. The Baja Peninsula, however, may serve as a migratory corridor for animals from both these subareas (Urbán et al. 2000). Interchange among the two subareas sampled off Japan, reported previously in a small sample (Darling and Mori 1993, Uchida et al. 1993 ) and found in this study, occurred at a lower rate than expected if whales mixed randomly.

Humpback whales are probably also inhabiting regions that are unknown or unsampled. Humpback whales were hunted during the winter months at numerous other locations in the western North Pacific, even though whale occurrence off Taiwan, the Mariana Islands and the Marshall Islands is currently uncommon or unknown (Darling and Mori 1993). Humpback whales also winter at scattered locations along the Mexican mainland south of the subareas that have been sampled (Urbán and Aguayo 1987). One known wintering region not included in our sample is the coastal waters of Central America, especially Costa Rica and Panama (Steiger et al. 1991, Calambokidis et al. 2000). This is a region where humpback whales from the North Pacific mate and give birth to calves, although no photographs were available from 1991 to 1993 for this analysis. This region appears to be used by humpback whales that migrate almost exclusively from feeding areas off California, with limited evidence of interchange with whales wintering off mainland Mexico (Calambokidis et al. 2000).

\section{Site Fidelity and Interchange among Feeding Areas}

Site fidelity was strongest at the feeding areas. Resighting rates among years at most feeding areas were high and only limited between-area movements were seen. The low rate of among-year resightings for a few feeding areas such 
as off Kodiak and in the western Gulf of Alaska probably reflects a combination of low effort and large number of whales, of which relatively few have been sampled. Brueggeman et al. (1988) reported a minimum estimate of 1,247 humpback whales based on ship surveys in the Shumagin-Kodiak Island area of the western Gulf of Alaska, an area from which we had only 91 identifications. Many of the areas in the North Pacific where whales feed are remote and have not been sampled.

Interchange between feeding areas in the North Pacific found in this study has been previously documented among some of the areas we examined: interchange between California and British Columbia (Calambokidis et al. 1996), British Columbia and southeastern Alaska (Darling and McSweeney 1985), southeastern Alaska and the western Gulf of Alaska including Prince William Sound (Darling and McSweeney 1985, Baker et al. 1986, Perry et al. 1990, von Ziegesar et al. 1994, Waite et al. 1999), and among areas in the western Gulf of Alaska (Waite et al. 1999). Consistent with this study, such interchanges occur at low rates involving just a few whales. A relatively distinct feeding aggregation of humpback whales has been documented along the coast of California, Oregon, and Washington with little interchange with feeding areas farther north (Calambokidis et al. 1996). Although there was a steep drop in interchange at the Washington-British Columbia border, interchange rates also declined with distance within the feeding groups that range off California, Oregon, and Washington (Calambokidis et al. 1996). Humpback whales in the North Atlantic also show strong site fidelity to feeding areas with only limited interchange among these areas (Katona and Beard 1990, Clapham et al. 1993a).

Currently, it is not possible to evaluate the total number and nature of the divisions among most of the North Pacific feeding areas. Samples used in this study are centered at locations where field effort has been conducted and do not necessarily represent centers of distinct feeding areas. Examination of larger samples collected from a more complete sampling of all feeding areas will be required to assess whether there are specific boundaries or a more continuous distribution with interchange decreasing with distance. Also, habitat use may change as abundance increases.

\section{Migratory Movements of Whales}

Despite the site fidelity of humpback whales to specific areas, sightings between feeding areas and wintering regions have not generally followed a simple pattern to allow definition of an integrated wintering/feeding area population structure. Results of photo-identification studies conducted in the North Pacific over the past 20 yr provide additional insight into migratory destinations of these whales.

The findings of this study, combined with those from others, confirm the dichotomy in the migratory destinations of whales wintering in the different subareas of Mexico. Humpback whales from the Revillagigedos, for which our limited sample uncovered only one match to a feeding area (California), mi- 
grate to feeding areas off California, British Columbia, southeastern Alaska, Prince William Sound, and the Kodiak Island area (Gabriele et al. 1996, Calambokidis et al. 2000, Urbán et al. 2000). Consistent with this study, the rate at which whales from the Revillagigedos were seen at these feeding areas was extremely low. These results suggest that other feeding areas that have not been well sampled, such as the offshore waters of the Gulf of Alaska and the Aleutian Islands, are likely the primary destinations of these whales. Conversely, whales wintering off mainland and Baja Mexico have a high rate of movement to feeding areas such as California to Washington, where over 100 matches have been documented, and at lower rates to British Columbia, southeastern Alaska, Prince William Sound, and the western Gulf of Alaska (this study, Baker et al. 1986, Perry et al. 1990, Urbán et al. 2000).

We found that humpback whales migrate at varied rates between Hawaii and most of the feeding areas in the eastern and central North Pacific. The high match rate between whales feeding in southeastern Alaska and those wintering in Hawaii is consistent with several past studies (Darling and McSweeney 1985; Baker et al. 1985, 1986). A migration time of as short as $39 \mathrm{~d}$ has been recorded between these two areas (Gabriele et al. 1996). Several of the migratory transits between Hawaii and Alaska documented in this study were also very short, including an animal seen in southeastern Alaska through late January 1993 and then in Kauai 36 d later.

Some of the migratory destinations of humpback whales wintering in the western North Pacific have not previously been documented. Our finding of movement of a whale between Japan and Kodiak Island is consistent with Discovery tag recaptures that indicated whale movement between Ogasawara and Okinawa and feeding areas in the Bering Sea, on the southern side of the Aleutian Islands, and in the Gulf of Alaska (Nishiwaki 1966, Omura and Ohsumi 1964, Ohsumi and Masaki 1975). One whale tagged off Ogasawara in March was killed in June of the same year northwest of Japan, possibly indicating movement north towards the Kuril Islands (Nishiwaki 1966). Given these patterns, whale movements to feeding areas near Kodiak Island and northern British Columbia found in this study are not surprising. Similarly, the one whale that we found to move between Ogasawara, Japan, and a feeding area off southern British Columbia is the same individual $(0-112)$ as that reported by Darling et al. (1996, same transit). This study revealed a second whale that moved between Ogasawara and British Columbia, although this time to northern British Columbia.

\section{Population Structure}

An understanding of population structure of humpback whales in the North Pacific is crucial to estimating abundance. The population structure of humpback whales in the North Pacific is complex and problematic for applying capture-recapture models. It is clear from our study that the limited movements among many areas make it inappropriate to treat the North Pacific as a single population. 
There are measurable differences in genetic patterns (both mtDNA and nuclear DNA) among whales inhabiting different feeding areas, as well as less dramatic, but still significant differences among wintering regions. Significant differences in mtDNA haplotypes were found between 38 humpback whales biopsied in southeastern Alaska and 20 from central California, suggesting a long-term migration rate of less than one female per generation (Baker $e t$ al. $1990,1994)$. However, differences in nuclear DNA were not found between humpback whales off California and southeastern Alaska (Baker et al. 1993, Palumbi and Baker 1994), suggesting some reproductive interchange, recent or historical. A larger analysis of samples from 205 humpback whales from an expanded number of areas in the North Pacific confirmed highly significant differences in mtDNA among both feeding and wintering areas and weaker, although still significant differences in nuclear actin, intron, and microsatellite alleles (Baker et al. 1998). The differences in alleles were significant when tested based on two presumed "stocks" which compared the wintering and feeding areas of the eastern North Pacific (Mexico and California) against those from the central North Pacific (Hawaii and Alaska). Medrano-González et al. (1995) reported weak but significant differences in mtDNA haplotypes between humpback whales wintering off the Revillagigedos and those off the Mexican coast.

The occurrence of distinct feeding aggregations, as indicated by photographic identification and mtDNA, does not necessarily indicate an absence of some interbreeding among whales from these different groups. Because mtDNA is maternally transmitted, mtDNA differences among feeding grounds may only indicate that offspring return to their mothers' feeding area. Mattila et al. (1989) and Clapham et al. (1993b) have reported that breeding groups in the West Indies have included males and females from different feeding areas. Similarly, since humpback whales from feeding areas in both Alaska and California migrate to both Hawaii and Mexico (although with very different frequencies, Darling and McSweeney 1985, Baker et al. 1986, Perry et al. 1990, Calambokidis et al. 2000, Urbán et al. 2000), the opportunity does exist for whales to interbreed. Although the frequencies of mtDNA haplotypes on Mexican and Hawaiian wintering regions are significantly different, they are not as marked as between California and Alaska (Baker et al. 1994). This may reflect the mixing of whales from different feeding areas on the wintering regions or migration from as yet unsampled feeding areas (MedranoGonzález et al. 1995).

These genetic and demographic patterns of population structure appear to be quite different from those in the North Atlantic. Current evidence suggests that humpback whales from the feeding areas interbreed at a single wintering ground in the West Indies to form a single panmictic population (Mattila et al. 1989, 1994; Clapham et al. 19936; Larsen et al. 1996; Palsbøll et al. 1997; Smith et al. 1999).

Humpback whales appear to show a strong degree of site fidelity at feeding areas; movements among these areas are often limited and genetic differences are most pronounced. Although the boundaries of one distinct feeding ground 
in the North Pacific have been defined off California, Oregon, and Washington (Calambokidis et al. 1996), they may not be as easily defined in other areas. The nearly continuous distribution of humpback whales along their feeding range around the North Pacific may make setting exact borders for feeding aggregations impossible, even though animals might show a high degree of site fidelity. The pattern of decreasing interchange with distance seen among the sampled subareas along the coast of California, Oregon, and Washington (Calambokidis et al. 1996) may be a typical pattern all along the feeding range. Genetic and photographic identification research has been conducted in very limited areas. In particular, little research has been conducted in the Gulf of Alaska and along the Aleutian Islands.

The complexity of defining the population structure of humpback whales results from the difficulty in integrating the wintering and feeding areas into a single cohesive model. This is problematic currently because of the varied and sometimes unusual pattern of migratory destinations and the lack of information from many feeding areas. Although defining population structure based on wintering regions is currently traditional, it is important for management considerations not to lose sight of the strong site fidelity to specific feeding grounds. Commercial whaling off California and Washington in the early 1900 s provided a demonstration of the management implications of such fidelity. During an eight-year period 2,473 humpback whales were killed from three stations off California and Washington (Clapham et al. 1997). Although this hunting depleted the whale aggregations in this feeding area (as evidenced by a dramatic decline in catch rates), such a decline was not as apparent off Mexico because that wintering region includes whales from a number of feeding areas (Clapham et al. 1997).

Defining population structure based on whale distribution on the wintering grounds is more feasible currently than that based upon feeding areas because whales breed in the former, are more separated geographically by large distances, and most areas have been sampled using photo-identification methods and genetic analyses. Our results of relatively rare movements between wintering regions are consistent with the significant differences in mtDNA that have been found between whales off Hawaii and Mexico. We conclude that, while there is clear evidence for at least three subpopulations of humpback whales in the North Pacific (those that winter off Hawaii, Japan, and Mexico), a precautionary management approach should consider the evidence for up to six subpopulations (with subdivisions in Mexico and Japan, plus Central America). Our data from subareas of Mexico, though limited, indicate whales in the Revillagigedo Archipelago should be considered a separate subpopulation from the whales using mainland Mexico, as suggested by Barlow et al. (1997) and Urbán et al. (2000). This conclusion is based on evidence of limited interchange with mainland Mexico, evidence that these animals migrate to different feeding areas, and the weak mtDNA differences between this area and coastal Mexico (Medrano-González et al. 1995, Urbán et al. 2000). Similarly, the low rate of interchange between the two subareas of Japan and the limited evidence of potential differences in migratory destinations indicate 
these two wintering grounds may need to be considered as separate subpopulations. Finally, it is unclear if humpback whale use of Central American waters (Steiger et al. 1991, Calambokidis et al. 2000) represents a distinct wintering region or an extension of the Mexican mainland region.

\section{ACKNOWLEDGMENTS}

The work of many people went into this large project that integrated the data of sixteen research organizations from four countries. It was supported by Southwest Fisheries Science Center (SWFSC) and the National Marine Mammal Laboratory (NMML); one author (JB) and Douglas DeMaster served as COTRs. This project would not be possible without the collaboration of many researchers who generously agreed to provide their data. Organizations supporting these researchers included Kewalo Basin Marine Mammal Laboratory (University of Hawaii), Hawaii Whale Research Foundation, Moss Landing Marine Laboratory (MLML), Universidad Autónoma de Baja California Sur (UABCS), Universidad Nacional Autónoma de México (UNAM), Ogasawara Marine Center, Okinawa Expo Aquarium, Canadian Department of Fisheries and Oceans, WWF-Japan, Cascadia Research Collective, Center for Whale Research (CWR), Vancouver Aquarium, Glacier Bay National Park, J. Straley Investigations, North Gulf Oceanic Society (NGOS), NMML, and SWFSC. In addition to the authors, a number of people had key roles in the collecting or cataloging photographs used in this study. They included: John Ford of the Vancouver Aquarium, Janice Waite at the NMML, Mario Salinas at UNAM, Kyoichi Mori currently with the Ogasawara Whale Watching Association, Diane Claridge and Prentice Bloedel at CWR, Craig Matkin with NGOS, and Tom Norris of MLML.

Many other people and organizations assisted in the funding and collection of data in the individual studies, including at the Revillagigedos: the Secreteria de Marina (Sector Naval, Isla Socorro), Consejo Nacional de Ciencia y Tecnología (CONACyT), Instituto Nacional de Ecología (INE-SEMARNAP), Africam Safari (E. Camacho), Whale and Dolphin Conservation Society, W. Rossiter and the Cetacean Society International, A. Aguayo, M Arias, M. Cannava, E. Connors, L. Flores, M. García, L. Medrano, C. Olivera, I. Salas, L. Sarti, and N. Vargas; off mainland Mexico: CONSCyT, INE-SEMARNAP, Centro de Estudios Tecnológicos del Mar \#6, Africam Safari (E. Camacho), Earthwatch, A. Aguayo, A. Carrera, G. Goméz, E. Jiménez, L. Medrano, S. Santoyo, M. J. Vázquez, and students and colleagues from the UNAM; off Baja: CONACyT, INE-SEMARNAP, Earthwatch, A. Jaramillo, S. Chávez, J. C. Salinas, and E. Vázquez; off Ogasawara: the Ogasawara Village; off Okinawa: the Tpkai Foundation, Nagoya; off Maui: Whale Aid, Captain Zodiac, Southern Illinois University at Edwardsville, Jill Mickelsen, David Glickman, and Doug Perrine; off Kauai: Whale Aid, the American Cetacean Society, the Animal Behavior Society, Sigma Xi, the American Museum of Natural History, the Myers Foundation for Marine Research, the Packard Foundation, A'TOC, D. Shapiro, T. Jennsen, G. Kent, J. Lemire, and others; off Kodiak and western Gulf of Alaska: K. Balcomb-Bartok, B. Caruso, T. Chandler, K. Chumbley, D. Ellifrit, J. Evenson, C. Hutchinson, J. Jacobsen, J. Lerczak, B. Mathews, B. Miller, R. Osborne, R. Ream, J. Sease, F. Sharpe, J. Stern, M. Strick, J. Swenson, and R. Towell; off California: Pacific Cetacean Group, MLML, SWFSC, Oceanic Society Expeditions, and Shearwater Journeys, and included N. Black, T. Chandler, K. Flynn, Z. Thomas, P. Rudolph, A. Reitsch, D. Meister, J. Quan, L. Randolph, Z. Schwartz, A. Rebollo, A. Randle, T. Kieckhefer, P. Howorth, R. Smith, E. Martin, and others.

Photograph grading and matching was completed with the help of Darcy Bristow, Dave Ellifrit, Cherish Morrison-Price, Jennifer Quan, Joy Sales, and Emily Walton. René DeVito assisted with the preparation of the report. Phil Clapham and Scott Baker 
provided comments on earlier drafts of the manuscript. We thank all of the people and organizations.

\section{Literature Cited}

Allen, J. M., H. C. Rosenbaum, S. K. Katona, P. J. Clapham and D. K. Mattila. 1994. Regional and sexual differences in fluke pigmentation of humpback whales (Megaptera novaeangliae) from the North Atlantic Ocean. Canadian Journal of Zoology 72:274-279.

Baker, C. S., AND L. M. HeRman. 1981. Migration and local movement of humpback whales (Megaptera novaeangliae) through Hawaiian waters. Canadian Journal of Zoology 59:460-469.

Baker, C. S., L. M. Herman, A. Perry, W. S. Lawton, J. M. Straley and J. H. Straley. 1985. Population characteristics and migration of summer and lateseason humpback whales (Megaptera novaeangliae) in southeastern Alaska. Marine Mammal Science 1:304-323.

Baker, C. S., L. M. Herman, A. Perry, W. S. Lawton, J. M. Straley, A. A. Wolman, G. D. Kaufman, H. E. Winn, J. D. Hall, J. M. Reinke and J. Östman. 1986. Migratory movement and population structure of humpback whales (Megaptera novaeangliae) in the central and eastern North Pacific. Marine Ecology Progress Series 31:105-119.

Baker, C. S., S. R. Palumbi, R. H. Lambertson, M. T. Weinrich, J. Calambokidis AND S. J. O'Brien. 1990. Influence of seasonal migration on geographic distribution of mitochondrial DNA haplotypes in humpback whales. Nature (London) 344:238-240.

Baker, C. S., D. A. Gilbert, M. T. Weinrich, R. Lambertsen, J. Calambokidis, B. McArdie, G. K. Chambers and S. J. O'Brien. 1993. Population characteristics of DNA fingerprints in humpback whales (Megaptera novaeangliae). Journal of Heredity 84:281-290.

Baker, C. S., R. B. Slade, J. L. Bannister, R. B. Abernethy, M. T. Weinrich, J. Lien, J. Urbán-R., P. Corkeron, J. Calambokidis, O. Vasquez and S. R. Palumbi. 1994. Hierarchical structure of mitochondrial DNA gene flow among humpback whales, world-wide. Molecular Ecology 3:313-327.

Baker, C. S., L. Medrano-Gonzalez, J. Calambokidis, A. Perry, F. Pichler, H. RoSenbaum, J. M. Straley, J. Urbán-Ramirez, M. Yamaguchi and O. von Ziegesar. 1998. Population structure of nuclear and mitochondrial DNA variation among humpback whales in the North Pacific. Molecular Ecology 7:695-708.

BARLOW, J. 1994. Recent information on the status of large whales in California waters. NOAA Technical Memorandum NOAA-TM-NMFS-SWFSC-203. National Technical Information Service, 5285 Port Royal Road, Springfield, Virginia 22167. $27 \mathrm{pp}$.

Barlow, J., K. A. Forney, P. S. Hill, R. L. Brownell, Jr., J. V. Carretta, D. P. DeMaster, F. Julian, M. S. Lowry, T. Ragen and R. R. Reeves. 1997. U.S. Pacific marine mammal stock assessments: 1996. NOAA Technical Memorandum NMFS NOAA-TM-NMFS-SWFSC-248. National Technical Information Service, 5285 Port Royal Road, Springfield, Virginia 22167. 223 pp.

Berzin, A. A., AND A. A. Rovnin. 1966. The distribution and migrations of whales in the northeastern part of the Pacific, Chuckchee and Bering Seas. Pages 179207 in K. I. Panin, ed. Soviet research on marine mammals in the Far East. Izvestiya Tikhoakeanskogo Nauchno-issledovatel'skogt Institud Rybnogo Khozyaistad I Okeanografii.

Brueggeman, J. J., G. A. Green, R. W. Tressler and D. G. Chapman. 1988. Shipboard surveys of endangered cetaceans in the northwestern Gulf of Alaska. Report to the U.S. Minerals Management Service, Alaska OCS Office and NOAA Office 
of Oceanography and Marine Assessment, Alaska Office, by Ebasco Environmental and Ecological Consulting, Inc., $10900 \mathrm{NE} 8^{\text {th }}$ Street, Bellevue, Washington. $162 \mathrm{pp}$.

Calambokidis, J., J. C. Cubbage, G. H. Steiger, K. C. Balcomb and P. Bloedel. 1990. Population estimates of humpback whales in the Gulf of the Farallones, California. Report of the International Whaling Commission (Special Issue 12):325-333.

Calambokidis, J., G. H. Steiger, J. R. Evenson, K. R. Flynn, K. C. Balcomb, D. E. Claridge, P. Bloedel, J. M. Straley, C. S. Baker, O. von Ziegesar, M. E. Dahlheim, J. M. Waite, J. D. Darling, G. Ellis and G. A. Green. 1996. Interchange and isolation of humpback whales off California and other North Pacific feeding grounds. Marine Mammal Science 12:215-226.

Calambokidis, J., G. H. Steiger, K. Rasmussen, J. Urbán R., K. C. Balcomb, P. Ladrón de Guevara, M. Salinas Z., J. K. Jacobsen, C. S. Baker, L. M. Herman, S. Cerchio and J. D. Darinng. 2000. Migratory destinations of humpback whales from the California, Oregon and Washington feeding ground. Marine Ecology Progress Series 192:295-304.

Carlson, C. A., C. A. Mayo and H. Whitehead. 1990. Changes in the ventral fluke pattern of the humpback whale (Megaptera novaeangliae), and its effect on matching; evaluation of its significance to photo-identification research. Report of the International Whaling Commission (Special Issue 12):105-111.

CERCHIO, S. 1998. Estimates of humpback whale abundance off Kauai, 1989 to 1993: Evaluating biases associated with sampling the Hawaiian Islands breeding assemblage. Marine Ecology Progress Series 175:23-34.

Cerchio, S., C. M. Gabriele, T. F. Norris and L. M. Herman. 1998. Movements of humpback whales between Kauai and Hawaii: Implications on population structure and abundance estimation in the Hawaiian Islands. Marine Ecology Progress Series 175:13-22.

Clapham, P. J., L. S. Barafe, C. A. Carlson, M. A. Christian, D. K. Mattila, C. A. Mayo, M. A. Murphy and S. Pittman. 1993a. Seasonal occurrence and annual return of humpback whales, Megaptera novaeangliae, in the southern Gulf of Maine. Canadian Journal of Zoology 71:440-443.

Clapham, P. J., D. K. Mattila and P. J. Palsbøil. 19936. High-latitude-area composition of humpback whale competitive groups in Samana Bay: further evidence for panmixis in the North Atlantic population. Canadian Journal of Zoology 71: $1065-1066$.

Clapham, P. J., S. Leatherwood, I. Szczepaniak and R. L. Brownell, JR. 1997. Catches of humpback and other whales from shore stations at Moss Landing and Trinidad, California, 1919-1926. Marine Mammal Science 13:368-394.

Darirng, J. D., ANd S. Cercho. 1993. Movement of a humpback whale (Megaptera novaeangliae) between Japan and Hawaii. Marine Mammal Science 9:84-89.

Darling, J. D., and C. M. Jurasz. 1983. Migratory destinations of North Pacific humpback whales (Megaptera novaeangliae). Pages 359-368 in R. Payne, ed. Communication and behavior of whales. Westview Press, Boulder, CO.

Darinng, J. D., AND D. J. MCSweENEY. 1985. Observations of the migrations of North Pacific humpback whales (Megaptera novaeangliae). Canadian Journal of Zoology 63:308-314.

Daring, J. D., AND K. Mori. 1993. Recent observations of humpback whales (Megaptera novaeangliae) in Japanese waters off Ogasawara and Okinawa. Canadian Journal of Zoology 71:325-333.

Darling, J. D., and H. Morowitz. 1986. Census of "Hawaiian" humpback whales (Megaptera novaeangliae) by individual identification. Canadian Journal of Zoology 64:105-111.

Darling, J. D., J. Calambokidis, K. C. Baicomb, P. Blogdel, K. Flynn, A. Mochizuki, K. Mori, F. Sato, H. Suganuma and M. Yamaguchi, 1996. Movement of a 
humpback whale (Megaptera novaeangliae) from Japan and British Columbia and return. Marine Mammal Science 12:281-287.

Donovan, G. P. 1991. A review of IWC stock boundaries. Report of the International Whaling Commission (Special Issue 13):39-68.

Gabriele, C. M., J. M. Straley, L. M. Herman and R. J. Coleman. 1996. Fastest documented migration of a North Pacific humpback whale. Marine Mammal Science 12:457-464.

Helweg, D. A., L. M. Herman, S. Yamamoto and P. H. Forestell. 1990. Comparison of songs of humpback whales (Megaptera novaeangliae) recorded in Japan, Hawaii, and Mexico during the winter of 1989. Scientific Reports of the Cetacean Research Institute 1:1-12.

IVASHIN, M. V., AND A. A. Rovnin. 1967. Some results of the Soviet whale marking in the waters of the North Pacific. Norsk Hvalfangst-Tidende 57:123-129.

Katona, S. K., And J. A. Beard. 1990. Population size, migrations and feeding aggregations of the humpback whale (Megaptera novaeangliae) in the western North Atlantic. Report of the International Whaling Commission (Special Issue 12): 295-305.

KellogG, R. 1928. What is known about the migrations of some of the whalebone whales. Pages 467-494 in Annual Reports of the Smithsonian Institution, Washington DC.

Larsen, A. H., J. Sigurjónsson, N. Oien, G. Vikingsson and P. J. Palsbøll. 1996. Population genetic analysis of nuclear and mitochondrial loci in skin biopsies collected from central and northeastern North Atlantic humpback whales (Megaptera novaeangliae): Population identity and migratory destinations. Proceedings of the Royal Society, London, Series B 263:1611-1618.

Mattlla, D. K., P. J. Clapham, S. K. Katona and G. S. Stone. 1989. Population composition of humpback whales, Megaptera novaeangliae, on Silver Bank, 1984. Canadian Journal of Zoology 67:281-285.

Mattila, D. K., P. J. Clapham, O. Vasquez and R. S. Bowman. 1994. Occurrence, population composition and habitat use of humpback whales in Samana Bay, Dominican Republic. Canadian Journal of Zoology 72:1898-1907.

Medrano-González, L., A. Aguayo-Lobo, J. Urbán-Ramirez and C. S. Baker. 1995. Diversity and distribution of mitochondrial DNA lineages among humpback whales, Megaptera novaeangliae, in the Mexican Pacific Ocean. Canadian Journal of Zoology 73: 1735-1743.

NishiwaKI, M. 1966. Distribution and migration of the larger cetaceans in the North Pacific as shown by Japanese whaling results. Pages 171-191 in K. S. Norris, ed. Whales, dolphins, and porpoises. University of California Press, Berkeley. CA.

Ohsumi, S., And Y. Masaki. 1975. Japanese whale marking in the North Pacific, 19631972. Bulletin of Far Seas Fisheries Research 12:171-219.

Omura, H., AND S. OHsumi. 1964. A review of Japanese whale marking in the North Pacific to the end of 1962, with some information on marking in the Antarctic. Norsk Hvalfangst-Tidende 4:90-112.

Palsbøll, P. J., J. Allen, M. Bérubé, P. J. Clapham, T. P. Feddersen, P. S. Hammond, R. R. Hudson, H. Jórgensen, S. Katona, A. H. Larsen, F. Larsen, J. Lien, D. K. Mattila, J. Sigurjónsson, R. Sears, T. Smith, R. Sponer, P. Stevick and N. OIEN. 1997. Genetic tagging of humpback whales. Nature, London 388:767769.

Palumbi, S. R., And C. S. Baker. 1994. Contrasting population structure from nuclear intron sequences and mtDNA of humpback whales. Molecular Biology and Evolution 11:426-435.

Payne, R. S., ANd L. N. Guinee. 1983. Humpback whale (Megaptera novaeangliae) songs as an indicator of "stocks." Pages 333-358 in R. Payne, ed. Cornmunication and Behavior of Whales. Westview Press, Boulder, CO.

Perry, A., C. S. Baker and L. M. Herman. 1990. Population characteristics of indi- 
vidually identified humpback whaies in the central and eastern North Pacific: A summary and critique. Report of the International Whaling Commission (Special Issue 12):307-317.

PIKE, G. C. 1953. Colour pattern of the humpback whales from the coast of British Columbia. Journal of the Fisheries Research Board of Canada 171:1-54.

Rosenbaum, H. C., P. J. Clapham, J. Alien, M. Nicole-Jenner, C. Jenner, L. FlorezGonzález, J. Urbán R., P. Ladrón G., K. Mori, M. Yamaguchi and C. S. Baker. 1995. Geographic variation in ventral fluke pigmentation of humpback whale Megaptera novaeangliae populations worldwide. Marine Ecology Progress Series 124:1-7.

Smith, T. D., J. Ailen, P. J. Clapham, P. S. Hammond, S. Katona, F. Larsen, J. Lien, D. Mattila, P. J. Paisboll, J. Sigurjónsson, P. T. Stevick and N. Oien. 1999. An ocean-wide mark-recapture study of the North Atlantic humpback whale ( $\mathrm{Me}$ gaptera novaeangliae). Marine Mammal Science 15:1-32.

Steiger, G. H., J. Calambokidis, R. Sears, K. C. Balcomb and J. C. Cubbage. 1991. Movement of humpback whales between California and Costa Rica. Marine Mammal Science 7:306-310.

Tomilin, A. G. 1957. Mammals of the USSR and adjacent countries. Volume 9. Akademii Nauk SSSR, Moskow (translated by the Israel Program for Scientific Translations, Jerusalem, 1967).

Uchida, S., N. Higashi and A. Takemura. 1993. Preliminary report of humpback whale of Okiniwa, Japan. International Marine Biological Research Institute, Kamogawa, Japan. IBI Reports: 57-67.

URbÁn, J., AND A. Aguayo. 1987. Spatial and seasonal distribution of the humpback whale, Megaptera novaeangliae, in the Mexican Pacific. Marine Mammal Science 3: 333-344.

Urbán, J., C. Alvarez F., M. Salinas Z., J. Jacobsen, K. C. Balcomb, A. Jaramilio L., P. Ladrón de Guevara P. and A. Aguayo L. 1999. Population size of the humpback whale (Megaptera novaeangliae) in waters off the Pacific Coast of Mexico. Fishery Bulletin, U.S. 97:1017-1024.

Urbán R., J., A. Jaramilio L., A. Aguayo L., P. Ladrón de Guevara P., M Salinas Z., C. Alvarez F., L. Medrano G., J. K. Jacobsen, K. C. Balcomb., D. E. Claridge, J. Calambokidis, G. H. Steiger, J. M. Straley, O. von Ziegesar, J. M. Waite, S. Mizroch, M. E. Dahlheim, J. D. Darling and C. S. Baker. 2000. Migratory destinations of humpback whales wintering in the Mexican Pacific. Journal of Cetacean Research and Management 2:101-110.

von Ziegesar, O., E. Miller and M. E. DahlHeim. 1994. Impacts on humpback whales in Prince William Sound. Pages 173-191 in T. R. Loughlin, ed. Marine mammals and the Exxon Valdez. Academic Press, San Diego, CA.

Waite, J. M., M. E. Dahlheim, R. C. Hobbs, S. A. Mizroch, O. von Ziegesar-Matkin, L. M. Herman AND J. Jacobsen. 1999. Evidence of a feeding aggregation of humpback whales (Megaptera novaeangliae) around Kodiak Island, Alaska. Marine Mammal Science 15:210-220.

Received: 13 January 1999

Accepted: 20 March 2001 